\title{
Partial Rootzone Drying Irrigation Modulates Transpiration of Olive Trees ${ }^{\dagger}$
}

\author{
Anabela A. Fernandes-Silva ${ }^{1,2}, *\left(\mathbb{D}\right.$, António Esteves ${ }^{2}$, Manuela Correia ${ }^{3}$ and Francisco Lúcio Santos 4 (D) \\ 1 Centre for Research and Technology of Agro-Environment and Biological Sciences (CITAB), \\ University of Trás-os-Montes e Alto Douro, Quinta dos Prados, 5000-801 Vila Real, Portugal \\ 2 Agronomy Department, School of Agrarian and Veterinary Sciences, University of Trás-os-Montes e Alto Douro, \\ Quinta dos Prados, 5000-801 Vila Real, Portugal; al39510@utad.eu \\ 3 MED Mediterranean Institute for Agriculture, Environment and Development, Universidade de Évora, \\ Pólo da Mitra, Ap. 94, 7006-554 Évora, Portugal; mmsc@uevora.pt \\ 4 ICAAM-Instituto de Ciências Agrárias e Ambientais Mediterrânicas, Universidade de Évora, \\ Núcleo da Mitra, Ap. 94, 7002-554 Évora, Portugal; fls@uevora.pt \\ * Correspondence: anaaf@utad.pt \\ + Presented at the 1st International Electronic Conference on Plant Science, 1-15 December 2020; Available \\ online: https:/ / iecps2020.sciforum.net/.
}

Citation: Fernandes-Silva, A.A.; Esteves, A.; Correia, M.; Santos, F.L. Partial Rootzone Drying Irrigation Modulates Transpiration of Olive Trees. Biol. Life Sci. Forum 2021, 4, 78. https://doi.org/10.3390/IECPS202008844

Academic Editor: Yoselin

Benitez-Alfonso

Published: 2 December 2020

Publisher's Note: MDPI stays neutral with regard to jurisdictional claims in published maps and institutional affiliations.

Copyright: (c) 2020 by the authors. Licensee MDPI, Basel, Switzerland. This article is an open access article distributed under the terms and conditions of the Creative Commons Attribution (CC BY) license (https:/ / creativecommons.org/licenses/by/ $4.0 /)$.

\begin{abstract}
Water scarcity and the increasing demand for irrigation in olive orchards lead to the adoption of deficit irrigation approaches to save water. A partial rootzone drying (PRD) irrigation technique has been proposed for woody crops as an agronomic practice to improve water productivity. This study was conducted to evaluate the effects of this irrigation strategy on water relations and transpiration of olive trees (cv. Cobrançosa) under climate conditions in the northeast of Portugal during the summer season of 2014. Two irrigation treatments were used: control (FI), irrigated with $100 \%$ of the estimated crop evapotranspiration (ET) and $\mathrm{PRD}_{50}$, irrigated with $50 \%$ of the control (FI) on one side and switching every two weeks. Whole tree transpiration (T) was quantified by sap flow, which was monitored within the trunks of both the control (FI) and deficit irrigated (PRD $\left.\mathrm{P}_{50}\right)$ trees using the compensation heath-pulse technique. Foliage gas exchange and water potentials were determined throughout the experimental period. During the summer, daily transpiration reached roughly 27 and $43 \mathrm{~L} \mathrm{~d}^{-1}$ for $\mathrm{PRD}_{50}$ and FI olive trees, respectively, with a clear reduction of $37 \%$ in $\mathrm{PRD}_{50}$ olive trees. $\mathrm{PRD}_{50}$ showed statistically comparable values of water potentials to the control, which appeared to prevent an excessive drop in tree water status by modulating stomatal closure.
\end{abstract}

Keywords: Olea europaea L.; deficit irrigation; water relations; sap flow; heat-pulse

\section{Introduction}

The olive tree (Olea europaea L.) assumes an important role in the Mediterranean landscape, and Vilariça valley, located in the region of Tras-os-Montes in Portugal, is no exception. The region, which contains 75,266 ha of olive groves, is assumed to be the second most important area of the country $(22 \%$ of the total area). According to the Köppen-Geiger climate classification [1], this region has a Csa climate type, where summer is characterised by scarce rainfall, high temperatures and intense solar radiation, conditions that lead to the development of a high vapour pressure deficit. The olive tree is an evergreen tree known to be resistant to drought; however, as a consequence of that capacity, its photosynthesis activity decreases, limiting the growth rate and yield [2,3]. Thus, irrigation of olive trees has been adopted to overcome these negative impacts and ensure crop yield. However, increasing irrigated areas is very difficult in the olive industry due to water scarcity and increased competition with non-agricultural uses [4]. Therefore, great emphasis is placed on irrigation management in arid regions to increase water use efficiency leading to the adoption of deficit irrigation approaches to save water. Partial Rootzone Drying (PRD), derived from split-root research, is a well-documented technique 
of water-saving irrigation [5-7]. The technique was developed based on understanding the physiological mechanisms controlling plant transpiration and root-shoot signalling under water deficits. It consists in irrigating only one side of the rootzone so that the plant can be simultaneously exposed to both wet and dry soils. This technique has already been successfully tested on several trees [8-11]. In olive, different studies have shown that PRD irrigation affects water relations, namely leaf water potential and stomatal conductance [12-14], vegetative growth [14], with minimal impacts on yield [15] and beneficial effects on olive oil quality [16]. The evaluation of olive tree water use can be assessed by sap flow measurements using the heat compensation pulse technique [17-19]. This study aims to assess the effects of PRD irrigation on water relations, sap flow and transpiration of olive trees (cv. Cobrançosa) under the hot and dry climate conditions in the northeast of Portugal during the summer season of 2014.

\section{Experiments}

\subsection{Field Conditions and Plant Material}

The field trial was conducted in 2014 in a 12-year-old organic commercial olive (cv. 'Cobrançosa') orchard located in Vilariça valley (Trás-os-Montes, Portugal, $41.3^{\circ} \mathrm{N}, 7.0^{\circ} \mathrm{W}$, $150 \mathrm{~m}$ altitude), a typical olive-growing area of northeast Portugal. The climate in this area is Mediterranean (IPMA, 2015), with an average rainfall of $520 \mathrm{~mm}$ concentrated from autumn to spring and $1130 \mathrm{~mm}$ of average $\mathrm{ET}_{0}$. The soil is classified as Eutric Leptosols developed on metamorphic rocks (schists) with a sandy loam texture. Two irrigation treatments were used: Fully irrigated (FI) control, for which the water applied equalled the difference between the maximum (estimated) ET and rainfall; and PRD irrigated, partial root drying system applying the same irrigation dose as FI to one half of the root system with the irrigated and drying halves of the rootzone alternating every two weeks. Watering was performed every day from June to October, corresponding to fruit set and fruit ripening stages, respectively. The experimental design was a complete randomised block, replicated three times. Each plot contained four central olive trees surrounded by 14 border trees. All measurements were conducted on the central trees of each plot.

\subsection{Sap Flow Measurements}

In order to evaluate sap flow rates and transpiration, trees represented in each irrigated treatment were selected, and a set of heat-pulse probes (Tranzflo, Palmerston, New Zealand) were installed into parallel holes drilled in a radial position (north and south side) into the semi-trunk of each tree, at the height of approximately $50 \mathrm{~cm}$. The heat-pulse gauge consists of a heater with a diameter of $1.8 \mathrm{~mm}$ and two temperature probes with the same diameter (one $15 \mathrm{~mm}$ downstream and the other at $5 \mathrm{~mm}$ upstream of the heater). Each temperature probe Copper-Constantan) had four thermocouple junctions spaced along the radius of the cross-section. In using the compensation heal-pulse technique [19], sap flow was obtained in $30 \mathrm{~min}$ intervals, and the transpiration of each tree was estimated as the average of the two sets of probes per tree.

\subsection{Tree Water Status and Stomatal Conductance}

The plant water status (predawn and midday stem water potential) was measured periodically during the 2014 cropping season using a Scholander pressure chamber (Soil Moisture Equipment Corp., PMS-1000, Corvallis, OR, USA). Predawn leaf potential ( $\left.\Psi_{\mathrm{PD}}\right)$ measurements were conducted before sunrise at approximately 04:30 while midday measurements of stem water potential $\left(\Psi_{\text {stem }}\right)$ were recorded between at midday on a small leafy shoot near the trunk that had been covered with aluminium foil for at least $1 \mathrm{~h}$ before measuring. Measurements of water potential were recorded from six plants in each irrigated treatment.

Leaf stomatal conductance (gs) was measured midday with a portable porometer (Delta-T AP4, Delta-T Devices, Cambridge, UK). The device was calibrated before each use with the supplied calibration plate. The terminal part of the main leaf lobe was placed into 
the cup on the head unit, which was positioned to the sun. Measurements were conducted during cloudless periods on six exposed leaves/treatments around noon.

\section{Results}

Figure 1 shows the diurnal pattern of sap flow in conditions of high and low evaporative demand. For both treatments, sap flow diurnal patterns showed a steep morning increase leading to maximum rates achieved at about midday, when vapour pressure deficit (VPD) was at its maximum, followed by a sustained gradual decrease until late afternoon (Figure 1). However, in conditions of high evaporative demand $\left(\right.$ ETo $\left.=7.0 \mathrm{~mm} \mathrm{~d}^{-1}\right)$, sap flow values of FI and PRD trees are similar in the first hours of the morning until 11:00. Afterwards, it fell in PRD trees, reaching a high rate of decrease at midday, being $37 \%$ lower than those of FI trees.

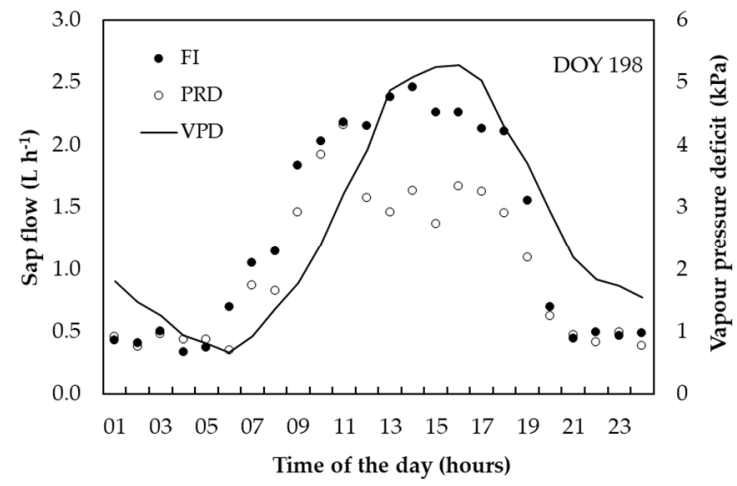

(a)

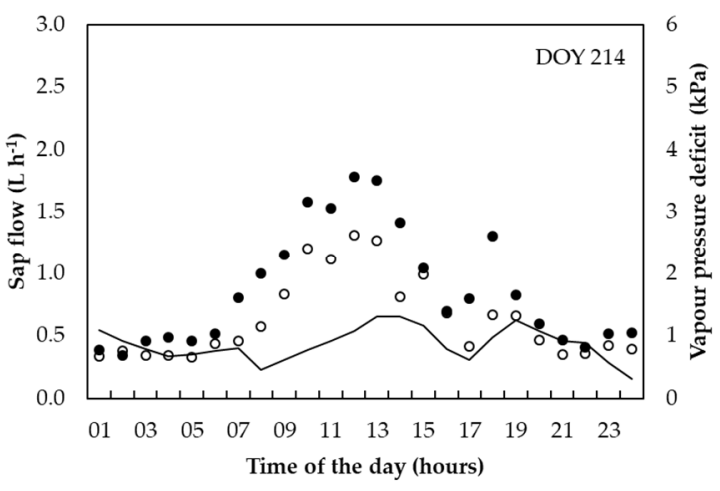

(b)

Figure 1. Diurnal pattern of sap flows and vapour pressure deficit (VPD) for full irrigated (FI) and partial rootzone drying olive trees. (a) A day of high evaporative demand $\left(E T o=7.0 \mathrm{~mm} \mathrm{~d}^{-1}\right)$; (b) a day of low evaporative demand $\left(\mathrm{ETo}=3.3 \mathrm{~mm} \mathrm{~d}^{-1}\right)$.

The seasonal evolution of daily transpiration (T) is presented in Figure 2. Averaged daily transpiration showed a progressive reduction during the season with maximum values at the end of July for both irrigated treatments when daily reference evapotranspiration was at its maximum. Such a reduction is quite similar between treatments. However, partial rootzone drying irrigated plants showed invariably lower daytime sap flow rates than full irrigated plants. Values of transpiration in FI plants ranged from 16 to $39.9 \mathrm{~L} \mathrm{~d}^{-1}$ at DOY $265\left(\right.$ ETo $\left.=1.9 \mathrm{~mm} \mathrm{~d}^{-1}\right)$ and $209\left(\right.$ ETo $\left.=7.6 \mathrm{~mm} \mathrm{~d}^{-1}\right)$, while in PRD plants, a minimum of 13.1 $\mathrm{L} \mathrm{d}^{-1}$ and a maximum of $27.3 \mathrm{~L} \mathrm{~d}^{-1}$ was attained on the same dates. Good agreement between measurements for daily water use and daily reference evapotranspiration was observed for both treatments $(p<0.05)$ with a coefficient of determination $\left(\mathrm{r}^{2}\right)$ of 0.74 for FI and 0.68 for PRD; although, the slope of the regression was significantly higher in FI plants compared to PRD trees.

Predawn values of water potential showed slight differences between FI and PRD treatments only in DOY 231, in which $\Psi_{\mathrm{PD}}$ of PRDI plants attained a minimum of $-1.16 \mathrm{MPa}$ (Figure 3). For FI trees, values were higher at $-0.65 \mathrm{MPa}$, whereas, for PRD plants, they were usually higher than $-0.80 \mathrm{MPa}$. Stem water potential was not significantly affected by PRD with values similar to FI plants, generally higher than -2.0 MPa. 


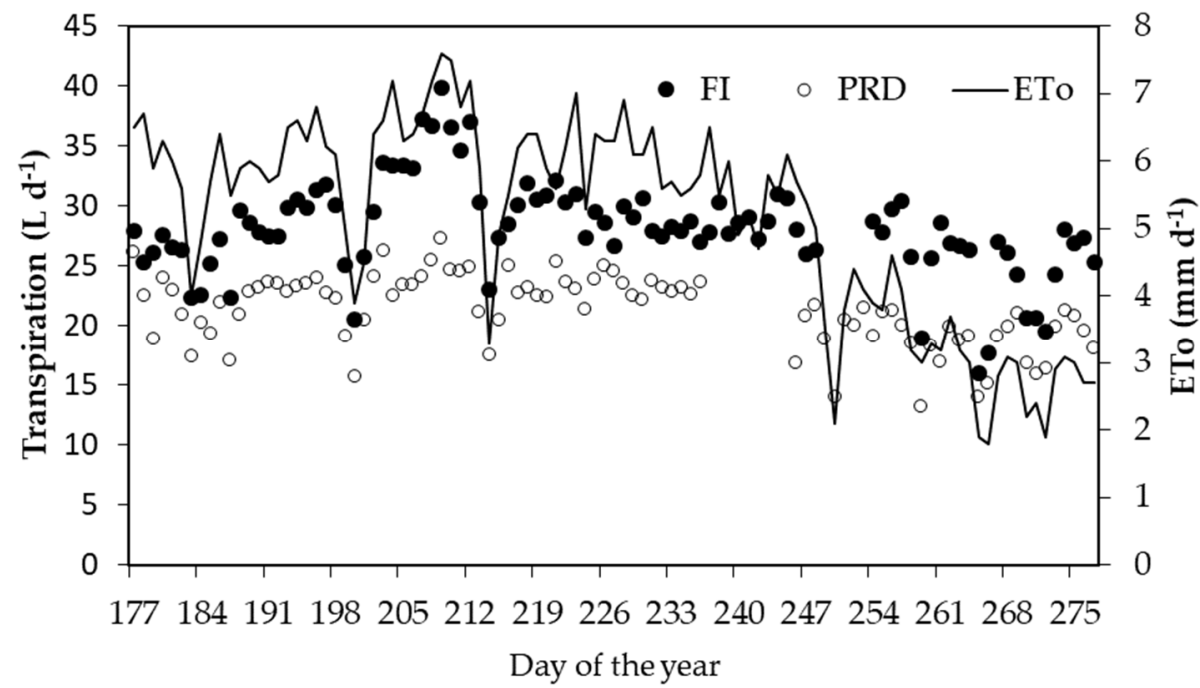

Figure 2. Seasonal evolution of daily reference evapotranspiration (ETo) and daily sap flux from 26 June 2014 until 4 October 2014, for full irrigated (FI) and partial rootzone drying (PRD) olive trees.

Day of the year

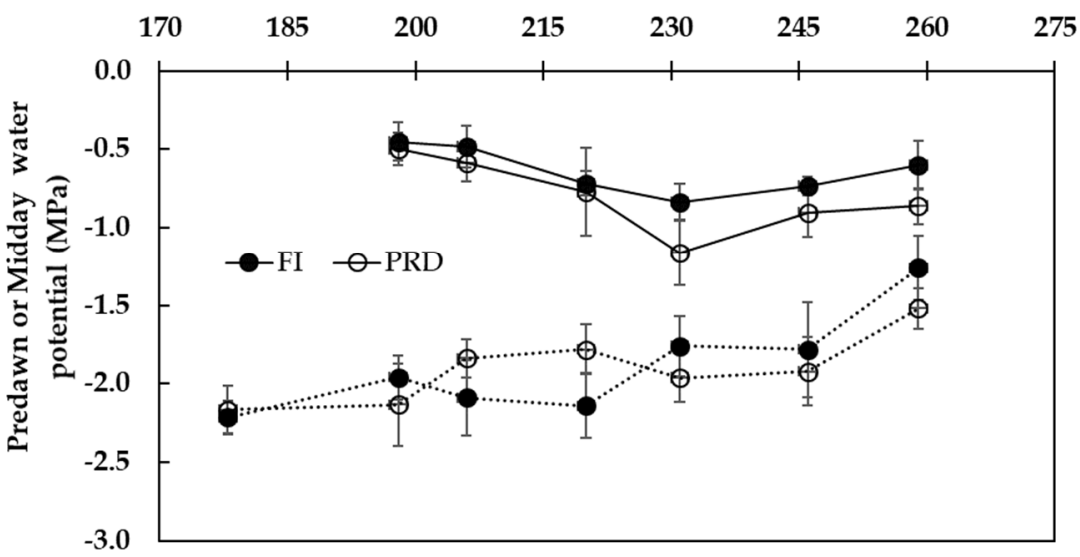

Figure 3. Time course of predawn (solid line) and stem midday (dashed line) water potential for full irrigated $(\mathrm{FI}, \bullet)$ and partial rootzone drying $(\mathrm{PRD}, \mathrm{O})$ olive trees. Values are means $( \pm \mathrm{SE})$ of six replicates.

The evolution of leaf gs measured throughout the olive growing season (Table 1) showed that control plants had significantly higher gs values than plants exposed to PRD, with a reduction of 33-45\%.

Table 1. Midday values of leaf stomatal conductance ( $\mathrm{gs}, \mathrm{mm} \mathrm{s}^{1}$ ) for the two irrigation treatments, during three representative days of the season. Values are means $( \pm \mathrm{SE})$ of six replicates.

\begin{tabular}{cccc}
\hline Irrigation Treatment & 24 July & 18 August & 15 September \\
\hline FI $^{1}$ & $6.1 \pm 0.17$ & $6.5 \pm 0.13$ & $7.2 \pm 0.12$ \\
PRD $^{1}$ & $4.1 \pm 0.32$ & $3.6 \pm 0.19$ & $4.7 \pm 0.74$ \\
\hline
\end{tabular}

${ }^{1}$ FI—full irrigated; PRD—partial rootzone drying.

\section{Discussion}

The values of $\Psi_{\mathrm{PD}}$ for FI plants are in accordance with those observed for other environmental conditions and cultivars in absence of water stress. The minimum $\Psi_{\mathrm{PD}}$ of $-1.16 \mathrm{MPa}$ indicated that plants did not undergo full recovery and hydration during the night, indicating a mild water stress. The absence of differences in midday values 
of $\Psi_{\text {stem }}$ between FI e PRD treatments associated with lower values of gs in PRD plants indicated a more conservative use of water than FI olive trees, preventing excessive water loss and avoiding leaf dehydration. A similar gs response was observed for other cultivars in field growing conditions and this decrease did not limit the overall photosynthesis process [12-14]. Some studies described a clear decrease in PRD olive trees' water status ( $\Psi_{\text {stem }}$ and relative water content), and others reported no differences [20], which appeared to prevent an excessive decline in tree water status by modulating stomatal closure. In our previous studies with this cultivar [21], we observed large fluctuations in midday gs with midday leaf water potential that were relatively stable and higher than $-3 \mathrm{MPa}$; a near-isohydric behaviour was also identified for cv. "Cobrançosa". The behaviour of PRD plants could be explained by the roots of the well-watered side, which maintained the plant water status while dehydrating roots; this may be responsible for inducing stomatal closure by sending chemical signals to the shoots through the xylem [22]. The PRD irrigated olive trees exhibited daily sap flow and transpiration consistently lower than FI plants throughout the season, which is further evidence that these plants effectively regulate water lost by stomatal closure, showing a more conservative water use strategy.

\section{Conclusions}

Preliminary results of this study performed in field-grown olive trees showed that partial rootzone drying irrigation did not affect plant water relations, as expressed by bulk leaf water potential when the total amount of water supplied to these adult olive trees was $50 \%$ of that supplied to control plants. The stomatal closure observed in PRD plants affects water use in $\mathrm{PRD}_{50}$ plants as shown by a clear reduction of sap flow and transpiration of mature olive trees. The coordinated adjustment in stomatal responses may represent an adaptive advantage in water deficit conditions induced by PRD irrigation. Further research is needed to understand the long-term yield and water use efficiency response of Cv. Cobrançosa to this irrigation strategy.

Supplementary Materials: The poster presentation is available online at https:/ /www.mdpi.com/ article/10.3390/IECPS2020-08844/s1.

Author Contributions: A.A.F.-S. wrote the paper, conceived, designed, performed the experiment and analysed the data; A.E. performed the experiment and analysed the data; M.C. analysed the data; F.L.S. analysed the data. All authors have read and agreed to the published version of the manuscript.

Funding: This work was supported by national funds from the Portuguese Foundation for Science and Technology (FCT) under the project UIBD/04003/2020 and a grant project [grant number PA 44662 IF0019] of the PRODER program of the Portuguese Ministry of Agriculture.

Conflicts of Interest: The authors declare no conflict of interest.

\section{References}

1. Kottek, M.; Grieser, J.; Beck, C.; Rudolf, B.; Rubel, F. World map of Köppen-Geiger climate classification update. Meteorol. Z. 2006, 15, 259-263. [CrossRef]

2. Mariscal, M.J.; Lavado, M.; Moñino, M.J.; Prieto, M.H. Olive tree (Olea europaea L. cv. "Morisca") response to sustained deficit irrigation in Extremadura. Acta Hortic. 2000, 537, 917-922. [CrossRef]

3. Fernandes-Silva, A.A.; Ferreira, T.C.; Correia, C.M.; Malheiro, A.C.; Villalobos, F.J. Influence of different irrigation regimes on crop yield and water use efficiency of olive. Plant Soil 2010, 333, 35-47. [CrossRef]

4. Fereres, E.; Goldhamer, D.A.; Parsons, L.R. Irrigation water management of horticultural crops. HortScience 2003, 38, 1036-1042. [CrossRef]

5. Dry, P.R.; Loveys, B.R. Grapevine shoot growth and stomatal conductance are reduced when part of the root system is dried. Vitis 1999, 38, 151-156.

6. Davies, W.J.; Wilkinson, S.; Loveys, B. Stomatal control by chemical signalling and the exploitation of this mechanism to increase water use efficiency in agriculture. New Phytol. 2002, 153, 449-460. [CrossRef] [PubMed]

7. Mingo, D.M.; Bacon, M.A.; Davies, W.J. Non-hydraulic regulation of fruit growth in tomato plants (Lycopersicon esculentum cv. Solairo) growing in drying soil. J. Exp. Bot. 2003, 54, 1205-1212. [CrossRef] [PubMed] 
8. dos Santos, T.P.; Lopez, C.M.; Rodríguez, M.L.; de Souza, C.R.; Maroco, J.P.; Perreira, J.S.; Silva, J.R.; Chaves, M.M. Partial rootzone drying: Effects on growth and fruit quality of field-grown grapevine (Vitis vinifera). Funct. Plant Biol. 2003, 30, 663-671. [CrossRef] [PubMed]

9. de Souza, C.R.; Maroco, J.P.; dos Santos, T.P.; Rodrigues, M.L.; Lopes, C.M.; Pereira, J.S.; Chaves, M.M. Partial rootzone drying: Regulation of stomatal aperture and carbon assimilation in field-grown grapevines (Vitis vinifera cv Moscatel). Funct. Plant Biol. 2003, 30, 653-662. [CrossRef] [PubMed]

10. Hutton, R.J.; Loveys, B.R. A partial root zone drying irrigation strategy for citrus-Effects on water use efficiency and fruit characteristics. Agric. Water Manag. 2011, 98, 1485-1496. [CrossRef]

11. Giuliani, M.M.; Eugenio Nardella, E.; Anna Gagliardi, A.; Gatta, G. Deficit Irrigation and Partial Root-Zone Drying Techniques in Processing Tomato Cultivated under Mediterranean Climate Conditions. Sustainability 2017, 9, 2197. [CrossRef]

12. Centritto, M.; Wahbi, S.; Serraj, R.; Chaves, M.M. Effects of partial rootzone drying (PRD) on adult olive tree (Olea europaea) in field conditions under arid climate. II. Photosynthetic responses. Agric. Ecosyst. Environ. 2005, 106, 303-311. [CrossRef]

13. Wahbi, S.; Wakrim, R.; Aganchich, B.; Serraj, R. Effects of partial rootzone drying (PRD) on adult olive tree (Olea europaea) in field conditions under arid climate. I. Physiological and agronomic responses. Agric. Ecosyst. Environ. 2005, 106, 289-301. [CrossRef]

14. Abboud, S.; Soumaya Dbarac, S.; Abidid, W.; Brahamb, M. Differential agro-physiological responses induced by partial rootzonedrying irrigation in olive cultivars grown in semi-arid conditions. Environ. Exp. Bot. 2019, 167, 103863. [CrossRef]

15. Aganchich, B.; Tahi, H.; Wahbi, S.; Elmodaffar, C.; Serraj, R. Growth, water relations and antioxidant defence mechanisms of olive (Olea europaea L.) subjected to Partial Root Drying (PRD) and Regulated Deficit Irrigation (RDI). Plant Biosyst. 2007, 141, 252-264. [CrossRef]

16. Aganchich, B.; El Antarib, A.; Wahbia, S.; Tahia, H.; Wakrima, R.; Serraja, R. Fruit and oil quality of mature olive trees under partial rootzone dryingin field conditions. Grasas y Aceites 2008, 59, 225-233.

17. Fernández, J.E.; Palomo, M.J.; Diaz-Espejo, A.; Clothier, B.E.; Green, S.R.; Giron, I.F.; Moreno, F. Heat-pulse measurements of sap flow in olives for automating irrigation: Tests, root flow and diagnostics of water stress. Agric. Water Manag. 2001, 51, 99-123. [CrossRef]

18. Tognetti, R.; d'Andria, R.; Morelli, G.; Calandrelli, D.; Fragnito, F. Irrigation effects on daily and seasonal variations of trunk sap flow and leaf water relations in olive trees. Plant Soil 2004, 263, 249-264. [CrossRef]

19. Santos, F.L.; Valverde, P.C.; Ramos, A.F.; Reis, J.L.; Castanheira, N.L. Water use and response of a dry-farmed olive orchard recently converted to irrigation. Biosyst. Eng. 2007, 98, 102-114. [CrossRef]

20. Ghrab, M.; Gargouria, K.; Bentaher, H.; Chartzoulakis, K.; Ayadia, M.; Mimound, M.B.; Masmoudid, M.M.; Mechliad, N.B.; Psarras, G. Water relations and yield of olive tree (cv. Chemlali) in response to partial root-zone drying (PRD) irrigation technique and salinity under arid climate. Agric. Water Manag. 2013, 123, 1-11. [CrossRef]

21. Fernandes-Silva, A.A.; López-Bernal, A.; Ferreira, T.C.; Villalobos, F.J. Leaf water relations and gas exchange response to water deficit of olive (cv. Cobrançosa) in field grown conditions in Portugal. Plant Soil 2016, 402, 191-209. [CrossRef]

22. Gowing, D.J.G.; Davies, W.J.; Jones, H.G. A positive rootsourcedsignal as an indicator of soil drying in apple Malus domestica Borkh. J. Exp. Bot. 1990, 41, 1535-1540. [CrossRef] 